\title{
PEMIKIRAN PENDIDIKAN ISLAM PERSPEKTIF KH. M. HASYIM ASY'ARI
}

\author{
Mukani $^{1}$
}

\begin{abstract}
Education thought of KH. M. Hasyim Asy'ari is the concept of character education, but also consistently gives positive contribution to the Indonesia civilization. Its dedication not only focuses on one field, but also on education, politic, social, religion, physical confrontation, organization, and the other intellectual works. Not only to educate young generation through Tebuireng Pesantren that was built, but for next generation, KH. M. Hasyim Asy'ari has inherited many books or holy books that able as main reference to search alternative solution of various problems that faced by nation. KH. M. Hasyim Asy'ari has been given fundamental conceptual framework for national education. Technical and operational steps must still be reviewed to implement the educational thinking. Figure of NU's founding at some point want to do the balancing for education in Indonesia. Not only formality aspects, but also substance of the meaning of education must be internalized and implemented in the life of students. In the end, Indonesia education is expected able to produce "product" that not only have cognitive intelligence (smart), but also have good virtue.
\end{abstract}

Keywords: Contribution, Struggle, Character Education, KH. M. Hasyim Asy'ari.

\section{A. Pendahuluan}

Dalam pemikiran inilah Kyai Hasyim sering menjadi referensi utama saat menjawab berbagai problematika yang dilakukan oleh beberapa pemikir pada masa sesudahnya. James J. Fox, antropolog dari Australian National University, menyebut Kyai Hasyim sebagai salah satu waliyullah yang sangat berpengaruh di Jawa karena memiliki kedalaman ilmu dan diyakini membawa berkah bagi pengikutnya. (Misrawi, 2010: 27). Selain itu, Kyai Hasyim juga dianggap sebagai sosok yang istimewa dan memiliki hubungan keluarga dengan para kyai di Jawa dan Prabu Brawijaya.

1 Dosen STIT Urwatul Wutsqo Bulurejo Jombang dan STAI Darussalam Krempyang Nganjuk 
Dalam bidang pluralisme beragama misalnya, pemikiran Kyai Hasyim lebih menunjukkan kepada sebuah kesadaran di antara masyarakat muslim untuk menghormati eksistensi masyarakat lain (the others). Di samping itu, pemikirannya tentang pluralisme beragama telah mendorong masyarakat muslim untuk bersikap adil kepada masyarakat lain atas dasar perdamaian dan saling menghormati. Kontribusi dalam bidang ini mampu menempatkan nama Kyai Hasyim sejajar dengan Ibnu Taimiyyah, tokoh besar bermadzhab Hambali dari Damaskus, Syiria. (Nurcholis, 1992: 602-604). Sedangkan menurut Howard M. Federspiel, Kyai Hasyim bukan merupakan sosok ulama yang menolak perubahan, tetapi, agaknya, sebagai sesorang yang tertarik kepada perubahan, meski hanya di dalam sistem tradisional Islam sendiri. (Howard, 2000: xi).

Dalam berbagai karya Kyai Hasyim, secara eksplisit maupun implisit, terdapat berbagai macam pemikiran Kyai Hasyim tentang pendidikan karakter yang harus dilakukan untuk mencapai tujuan pendidikan. Hal ini dimungkinkan mengingat, di samping sebagai seorang pemikir pendidikan, Kyai Hasyim merupakan sosok yang berkiprah secara langsung di dalam dunia pendidikan, sejak masih kecil hingga akhir hidupnya. Pemikiran Kyai Hasyim dalam bidang pendidikan karakter inilah yang hendak dibahas dalam tulisan ini, sebagai sebuah bidang yang banyak ditinggalkan saat mengkaji pemikiran tokoh yang pernah menjadi sebagai $R a^{\prime}$ is Akbar dari organisasi NU ini.

Kyai Hasyim merupakan tokoh yang memiliki sejarah aktivitas dan pemikiran sangat luas. Hal ini merupakan konskuensi logis dari bentang masa hidup yang cukup lama, mulai dari tahun 1871 sampai dengan tahun 1947, yang di antara itu telah terjadi berbagai peristiwa di Indonesia. Tentu saja peristiwa-peristiwa tersebut memiliki pengaruh dalam pemikiran Kyai Hasyim, baik secara langsung maupun tidak langsung. Dalam bidang pendidikan karakter, sebagai studi kasus, pemikiran Kyai Hasyim sangat dipengaruhi oleh tiga hal, yaitu setting politik, background keluarga dan riwayat pendidikan yang telah ditempuh. 


\section{B. Sekilas Perjuangan Kyai Hasyim}

\section{Setting Sosial Politik}

Periode Pertengahan dalam sejarah peradaban Islam, yaitu sekitar abad X-XV Masehi, merupakan periode yang harus dilalui masyarakat muslim dengan penuh kegelapan. Setelah berjaya dengan meraih supremasi dan dominasi di dunia internasional pada Periode Klasik, yaitu sekitar abad VII sampai X Masehi, masyarakat muslim harus berhadapan dengan berbagai permasalahan yang menyebabkan kemundurannya. Kondisi masyarakat muslim pada periode ini tidak lebih dari kondisi masyarakat Barat pada Periode Klasik. (Marshall, 1974: 48).

Kemunduran yang berlangsung selama berabad-abad tersebut, dirasakan hanya menyebabkan kemiskinan, kebodohan dan penderitaan sebagai akibat kekalahan dari bangsa Barat. Kolonialisme yang mencengkeram berbagai daerah muslim, atau setidaknya berpenduduk mayoritas muslim, telah menyadarkan masyarakat muslim terhadap ketertinggalan mereka. Ironinya, kolonialisme tersebut justeru dilakukan oleh bangsa-bangsa Barat yang pada Periode Klasik masih menjadi "murid yang baik" dari masa kejayaan peradaban Islam. (Nasution, 1992: 14). Perputaran sejarah ternyata telah membalikkan kondisi yang ada dan hal ini dicoba untuk segera direspon oleh masyarakat muslim agar tidak terus menerus berada dalam "kubangan penderitaan" tersebut.

Kesadaran inilah yang mendorong masyarakat muslim untuk segera meninggalkan "paradigma lama" menuju "paradigma baru" untuk merespon kondisinya yang semakin mundur tersebut. Gerakan modernisme, revivalisme, kebangkitan, pembaruan dan apapun namanya ketika itu, berupaya sekuat tenaga mengoptimalkan potensi yang dimiliki dalam diri masyarakat muslim untuk mengentas mereka dari Abad Kegelapan. Para pemikir muslim pun berlomba-lomba untuk mencari celah kelemahan masyarakat muslim yang kemudian digagas format baru untuk menutupinya guna memodernisasi diri mengikuti perkembangan jaman.

Pada periode selanjutnya, lahir berbagai gerakan Islam yang dipimpin oleh para tokohnya dan memiliki implikasi signifikan terhadap kebangkitan di daerah-daerah muslim, termasuk Indonesia. Tanah al-Jawi, sebagai term yang merujuk kepada daerah di sekitar Asia Tenggara saat ini, ternyata 
juga mengalami kebangkitan yang telah didahului di daerah Minangkabau, Sumatera Barat. (M. Iskandar dan A. Syahid, 2002: 313-316). Ini merupakan perkembangan yang luar biasa, mengingat Jawa pada periode sebelumnya merupakan daerah yang berhasil "memaksa” Islam untuk beradaptasi diri terlebih dahulu dengan kultur lama masyarakatnya yang masih kental dengan nuansa Hindu-Budha. Masyarakat Islam di Jawa lebih menunjukkan pola sinkritisme dari pada "Islam yang murni” dari Timur Tengah. (Fauzan, 2005: 46-47).

Gerakan kebangkitan Islam yang terjadi di Indonesia merupakan respon terhadap kebangkitan di dunia Islam pada umumnya. Gerakan kebangkitan ini pada awalnya masih murni berlatarbelakang dan bertujuan kepada terwujudnya pelaksanaan ajaran Islam secara benar, supaya tidak dipengaruhi oleh ajaran-ajaran agama lain atau kebudayaan lokal. Tetapi pada perkembangannya, gerakan kebangkitan Islam juga merambah kepada kebangkitan semangat nasionalisme dalam menentang kolonialisme terhadap daerah-daerah muslim. Meskipun demikian, awal mula gerakan kebangkitan ini berasal dari Timur Tengah yang masuk ke Indonesia dengan melalui empat jalur, yaitu (1) dengan menjadikan pemikiranpemikiran tokoh Timur Tengah sebagai mentor, seperti Jamaludin alAfghani, Muhammad Abduh, Rasyid Ridha dan sebagainya (2) melalui publikasi majalah mingguan al-Manar yang diterbitkan di Kairo sejak tahun 1896 (3) pengiriman penduduk Indonesia yang menjadi mahasiswa di Universitas Al-Azhar di Kairo, yang dianggap sebagai poros utama para tokoh reformasi muslim untuk mempersiapkan diri dalam menghadapi berbagai perubahan jaman modern (4) kolonialisme Belanda yang semakin efektif berkuasa di Nusantara dalam semua bidang kehidupan, termasuk agama, sehingga memberikan pengaruh kepada wacana intelektual yang berkembang saat itu.

Kolonialisme Belanda, di sisi lain, juga memiliki implikasi terbesar terhadap sejarah perkembangan pendidikan di Indonesia. Jika sebelumnya di Indonesia telah berdiri sekolah-sekolah keagamaan (Islam) yang hanya berorientasi kepada membaca al-Qur'an, praktek shalat dan dasar-dasar ajaran Islam, maka dengan kedatangan Belanda yang membawa sistem pendidikan Barat (Kristen), menjadikan pintu masuk bagi pelajaran ilmu pengetahuan sekuler dibuka, bahkan dilakukan pemberian subsidi 
dan penyusunan kurikulum. Polarisasi dalam sistem pendidikan ketika itu lambat laun akan menghasilkan golongan yang berbeda pula dalam masyarakat. Di satu sisi, sistem pendidikan tradisional Islam hanya melahirkan kaum agamawan yang tidak mampu meraih jabatan dalam sistem administratif pemerintah kolonial karena keterbatasan pemahaman mereka terhadap huruf Latin, di sisi lain sistem pendidikan Barat yang Kristen telah melahirkan golongan yang memiliki peluang besar untuk meraih posisi tersebut dengan memperoleh ketercukupan ekonomi yang menjanjikan. Golongan pertama diidentikkan dengan kaum santri dan golongan kedua disebut dengan kaum priyayi. Tentang dikotomi kedua golongan ini, (baca Clifford, 1960, Zaini, 1988).

Kyai Hasyim sendiri mengakui keberadaan dari perbedaan gerakan pembaruan yang dilakukan masyarakat muslim di Jawa sebelum dia dilahirkan. Dari sebelumnya yang bersifat homogen dengan berteologi al-Asy'ari, mengikuti ajaran tasawuf menurut Imam Al-Ghazali dan ajaran fiqh yang cenderung Syafi' i-sentris, terjadi arus besar yang memetakan peta pemikiran dan gerakan pembaruan menjadi dua, ortodoksi dan modernisasi. Gerakan model pertama merupakan golongan yang masih berpegang teguh kepada tradisi salafiyyah dengan berpedoman kepada buku-buku rujukan yang diakui validitasnya (mu'tabar) dan mempraktekkan ibadah-ibadah yang masih bersifat tradisional, seperti mengunjungi makam atau ziyarah qubur, washilah, talqin mayyit, tahlil, adanya syafa'at di hari kiamat nanti dan sebagainya. Di sisi lain, gerakan model kedua justeru berpendapat bahwa praktek-praktek tersebut bukan ajaran Islam, bahkan dihukumi haram. Kedua kelompok ini telah membentuk polarisasi dalam masyarakat Jawa dengan memunculkan permusuhan dan fanatisme yang berlebihan.

Dalam kondisi dunia Islam secara global yang sedang mengalami kebangkitan dan kolonialisme Belanda di Nusantara yang semakin mencengkeram dengan kuat, yang berimplikasi kepada kelahiran kebangkitan Islam di Indonesia, Kyai Hasyim dilahirkan. Dengan memiliki setting sosial politik sebagaimana diuraikan di atas, hal ini memiliki pengaruh yang signifikan terhadap pola perjuangan dan pemikiran Kyai Hasyim di kemudian hari. 


\section{Karya Intelektual}

Kyai Hasyim wafat pada hari Jumat Pon tanggal 25 Juli 1947 Masehi atau bertepatan dengan 7 Ramadhan 1366 Hijriyah pada pagi hari menjelang Subuh. Beberapa saat sebelum wafat, Kyai Hasyim mengalami pendarahan otak atau hersenbloeding setelah mendengar kabar terakhir dari Kyai Ghufran bersama dua orang utusan Bung Tomo tentang kekalahan Pasukan Sabilillah dan Hizbullah di Singosari Malang, sebagai pertahanan terakhir dari kedua pasukan tersebut, akibat serangan besar-besaran yang dilakukan Belanda di bawah pimpinan Jenderal S.H. Spoor. Serangan tentara Belanda ini menyebabkan jatuhnya banyak korban di pihak rakyat Indonesia.

Jenasah Kyai Hasyim kemudian dimakamkan pada siang harinya, hari itu juga, di kompleks pemakaman keluarga Pesantren Tebuireng. Atas jasajasa Kyai Hasyim dalam mendukung kemerdekaan RI, baik secara langsung maupun tidak langsung, terutama resolusi jihad-nya tanggal 22 Oktober 1945 yang berisi bahwa perang melawan Belanda dikategorikan sebagai perang suci atau jihad dan pengharamannya terhadap kaum muslim yang melaksanakan ibadah haji dengan menggunakan kapal milik Belanda, maka Kyai Hasyim ditetapkan sebagai Pahlawan Pergerakan Nasional. Penetapan ini berdasarkan Surat Keputusan Presiden Republik Indonesia Nomor 249/1964 tanggal 17 Nopember 1964.

Semasa hidup, Kyai Hasyim merupakan salah satu ulama penulis yang produktif pada jamannya. Tulisan-tulisan tersebut berbahasa Arab atau Jawa, baik yang berkaitan dengan masalah sosial, politik, pendidikan, pertanian, 'aqidah, fiqh, hadits, tashawuf maupun lainnya. Sebagian dari tulisan-tulisan tersebut sudah dicetak ulang dan bahkan diterjemahkan ke dalam bahasa Indonesia. Mayoritas artikel atau risalah yang ditulis menunjukkan respon Kyai Hasyim terhadap problematika yang dihadapi masyarakat. Resolusi Jihad, sebagai studi kasus, menunjukkan upaya ijtihad Kyai Hasyim yang sangat kreatif dan inovatif dalam membela kepentingan rakyat. Meski diakui semasa hidup Kyai Hasyim tidak pernah menulis sebuah buku yang utuh dan tebal, tetapi berupa risalah yang membahas tema aktual dalam masyarakat. Namun, risalah yang tipis itu tidak menunjukkan bobot mutu tentang karya tulis Kyai Hasyim.

Di antara tulisan-tulisan Kyai Hasyim tersebut adalah Adabul 'Alim wal Muta'allim, al-Nurul Mubin, al-Tanbihat wal Wajibat, al-Durarul Muntatsirah, 
al-Tibyan, al-Mawa'idz, Risalah Ahlissunnah wal Jama'ah, Dha'ul Mishbah, Ziyadatut Ta'liqat, al-Qanun al-Asasi Li Jam'iyyatin Nahdhatil 'Ulama, Arba'in Haditsah, al-Risalah fil 'Aqa'id, al-Risalah fil Tashawwufi, Tamyizul Haqq minal Bathil, Risalah fi Ta'kidil Akhdz bi Ahadil Madzahib al-A'immah al-Arba'ahi, Hasyiyah 'ala Fathur Rahman, al-Risalah Al-Tawhidiyyah, alQala'id,Risalah al-Jama'ah, Manasik Sughra, al-Jasus fi Ahkamin Nuqush dan sebagainya (Hadziq, 1995: 6-7). Di samping itu, pidato-pidato yang disampaikan Kyai Hasyim banyak dimuat oleh surat kabar, seperti Soeara Nahdlatoel Oelama, Soeara MIAI, Soeara Moeslimin Indonesia, Al-Djihad dan sebagainya.

\section{Character Education Perspektif KH. M. Hasyim Asy'ari}

Pemikiran Kyai Hasyim dalam bidang pendidikan merupakan dimensi menarik untuk dikaji, mengingat banyak tulisan Kyai Hasyim yang terkait pendidikan, baik secara langsung maupun tidak langsung. Meski demikian, pembahasan dalam sub bab ini berupaya melakukan sistemisasi terhadap dimensi yang luas itu. Dengan demikian, pembahasan ini diharapkan mampu memaparkan pemikiran pendidikan Kyai Hasyim secara deskriptif dan komprehensif.

\section{Konsep Manusia dan Pembagian Ilmu}

Kehadiran manusia dalam semesta ini, menurut Kyai Hasyim, setidaknya memiliki dua tugas yang harus dilaksanakan secara seimbang. Pertama adalah dalam kaitan kedudukannya sebagai ciptaan Tuhan ('abdullah). Dalam posisi ini, manusia dituntut menunjukkan tingkat ketaatannya kepada Tuhan yang telah menciptakan mereka, yang hal ini memiliki implikasi-implikasi positif dalam perkembangan alam semesta itu sendiri. Di sisi lain, manusia juga merupakan ciptaan Tuhan yang bertanggung jawab terhadap kelestarian semesta di sekelilingnya (khalifah fi al-ardh). Dalam mensukseskan tugas ini, manusia harus mau dan mampu berupaya seoptimal mungkin agar potensi yang terdapat di dalam dirinya membantu pelaksanaan tugas ini, seperti rasio, tenaga, emosi dan sebagainya. Dengan kedua tugas ini, diharapkan manusia memiliki keseimbangan (balancing) yang baik selama hidupnya. 
Manusia merupakan sosok yang penuh dengan potensi (fitrah) yang dibawanya sejak dilahirkan ke dunia. Pribadi dengan segala "keunikan" inilah yang mendorong banyak ahli untuk mengungkap misteri yang terdapat di dalamnya, hingga saat ini. Meskipun demikian, generalisasi dalam proses tersebut tetap dilakukan, yaitu bahwa manusia memiliki yang sama ketika baru dilahirkan. Hal ini, menurut Kyai Hasyim, berimplikasi ke dalam dunia pendidikan, bahwa harus dilakukan tindakan yang sama juga ketika mengembangkan potensi yang ada dan berproses dalam dunia pendididakan, tanpa adanya unsur diskriminasi (Asya'ary, 1417 H, 36-37).

Dalam konteks interaksi dengan yang lain, diperlukan upaya untuk mempererat persatuan dan kesatuan di antara sesama anggota masyarakat muslim. Ini perlu ditekankan untuk membangkitkan semangat masyarakat muslim dalam meraih supremasi di kancah internasional. Pengalaman sejarah peradaban Islam telah mengajarkan bahwa fanatisme terhadap golongan sendiri (ta'ashub) yang terjadi di masyarakat muslim saat itu hanya akan mengakibatkan perpecahan dan kekalahan ketika harus berhadapan dengan bangsa Barat.

Persatuan dan kesatuan tersebut tentu harus dijaga dengan baik dan tetap memperhatikan norma yang berlaku di masyarakat (Asy'ary, 1998: 9). Hal ini penting untuk ditekankan mengingat manusia adalah homo social yang eksistensinya sangat dipengaruhi oleh kesuksesannya dalam menjalin interaksi dengan manusia lain. Manusia tidak akan mampu kebutuhan hidupnya hanya dengan diri sendiri.

Di sisi lain, Kyai Hasyim membagi ilmu dalam pendidikan menjadi tiga kategori. Pertama adalah ilmu-ilmu yang berkaitan dengan fungsi utama manusia di alam semesta, yaitu sebagai 'abdullah, yang meliputi 'ilmu dzat al-'aliyah,'ilmu sifat, 'ilmu figh dan 'ilmu tasawuf. Ilmu pertama merupakan cabang yang membahas keimanan dan harus dipahami oleh manusia terlebih dahulu tentang hakekat Tuhan (theology), sebelum manusia tersebut menjalankan ritual-ritual yang terdapat dalam doktrin Islam. Ilmu kedua lebih menekankan pembahasannya kepada sifat-sifat yang dimiliki Tuhan itu sendiri, dalam kerangka konseptual ketika mengatur eksitensi alam semesta beserta isinya ini, seperti qudrah, iradah, bashar, kalam, sama' dan sebagainya. Ilmu ketiga membahas dan mengantarkan manusia kepada ketaatan dalam melaksanakan ritualitas sebagai hubungan vertikal 
( habl minallah) kepada Tuhan yang telah diajarkan dalam Islam dan harus dilaksanakan oleh masing-masing individu, seperti shalat, puasa, bersuci, haji dan sebagainya. Ilmu keempat membahas tentang berbagai keadaan (ahwal), tingkatan (maqam) dan rayuan-rayuan nafsu kebinatangan (nafs hayawaniyah) serta hal-hal yang berhubungan dengannya. Ilmu terakhir ini merupakan aktualitasasi dari nilai-nilai yang dikehendaki Tuhan dengan berbagai ritual yang dibahas pada ilmu ketiga, yang dengan itu semua diharapkan hubungan antar sesama hamba Tuhan (habl min alnas) terjaga dengan baik.

Kedua adalah ilmu-ilmu terkait al-Qur'an atau ilmu tafsir. Karena al-Qur'an merupakan kitab suci bagi masyarakat muslim dan induk dari semua ilmu yang ada, hal ini sangat ditekankan oleh Kyai Hasyim untuk dikuasai terlebih dahulu melalui pendidikan. Ketiga adalah ilmu hadits, yang telah dijadikan primary source pada periode sekarang, seperti kitab Shahih al-Bukhary, Shahih Muslim, Sunan Abu Dawud, Sunan al-Nasa'i, Sunan Ibn Majah, Sunan al-Kabir, Al-Muwatha' dan sebagainya.

Dengan pembagian ilmu yang rinci seperti diuraikan di atas, Kyai Hasyim memposisikan manusia pada kedudukan yang sangat penting dalam proses transformasi ilmu dari satu generasi ke generasi berikutnya. Artinya, di samping menjadikan ilmu bersifat dinamis, manusia merupakan unsur terpenting dalam menjaga tingkat validitas ilmu itu sendiri. Untuk itulah, manusia yang akan berproses dalam transformasi ilmu harus memiliki kriteria-kriteria tertentu (Asy'ary, 1998:17-18).

Oleh karena itu, seseorang yang menghendaki kesuksesan dalam proses transformasi ilmu harus mampu mempersiapkannya secara matang, bahkan sebagai antisipasinya jauh sebelum yang bersangkutan melangsungkan pernikahan(Asy'ary, 1999: 5). Dengan upaya ini, diharapkan dapat terlahir calon siswa yang memiliki tingkat keberagamaan dan intelektualitas yang baik, sebagai salah satu syarat dalam meraih kesuksesanan dalam belajarnya.

\section{Orientasi Pendidikan}

Berdasarkan pemikiran Kyai Hasyim tentang ilmu dalam perspektif pendidikan seperti telah diuraikan di atas, disimpulkan bahwa tujuan 
pendidikan, di samping pemahaman terhadap pengetahuan (knowledge), adalah pembentukkan good man yang penuh dengan pemahaman secara benar dan sempurna terhadap ajaran-ajaran Islam serta mampu mengaktualisasikan dalam kehidupan sehari-harinya secara konsisten.

Tujuan pendidikan ini mampu direalisasikan jika peserta didik mampu terlebih dahulu mendekatkan diri (muraqabah) kepada Tuhan dan ketika berproses dalam pendidikan, dirinya harus steril dari unsurunsur materalisme, seperti kekayaan, jabatan, popularitas dan sebagainya. Oleh karena itu, ketika peserta didik melakukan kesalahan, maka menjadi kewajiban guru untuk melakukan koreksi terhadap kesalahan tersebut. Kepada peserta didik yang belum mengetahui tentang suatu perbuatan itu sendiri, maka guru harus mampu menolongnya agar peserta didik memperoleh pemahaman yang benar. Dengan berdasarkan argumentasi seperti ini, maka Kyai Hasyim menggunakan term tarbiyyah untuk menunjuk substansi pendidikan.

Di sisi lain, praktek interaksi sosial dan realisasi ritualitas dalam doktrin Islam yang telah ditunjukkan dalam periode Nabi SAW sebenarnya merupakan refleksi dari hakikat ajaran Islam yang sebenarnya. Hal ini membawa implikasi kepada sebuah keharusan untuk meneladani segala hal yang telah dilakukan Nabi SAW dalam menjelaskan doktrin Islam tersebut. Dengan demikian, diharapkan Nabi SAW sebagai sosok yang sempurna dan telah berhasil mengekang nafsu kebinatangannya dijadikan public figur yang kepribadiannya tersebut harus ditiru peserta didik.

Pada periode sesudahnya, meskipun Kyai Hasyim mengecam keras berbagai praktek sufi pada jamannya yang keliru dan sesat, sebenarnya praktek-praktek sufi tertentu tetap dapat dijadikan pedoman dalam membentuk moralitas peserta didik yang dikehendaki, dengan pemahaman yang luas tentunya terhadap substansi sufisme itu sendiri (Khuluq, 2001:52). Hal ini berdasarkan fakta bahwa dalam doktrin sufi mengajarkan tentang kesederhanaan hidup, meningkatkan ketakwaan, penjagaan terhadap nilainilai moral dan sebagainya. Inilah yang dikehendaki Kyai Hasyim sebagai orientasi pendidikan yang mengarah kepada pembentukan perilaku peserta didik yang baik, di samping tentunya pemahaman terhadap knowlage secara mendalam. 


\section{Materi Pembelajaran}

Pemikiran Kyai Hasyim dalam aspek ini lebih banyak dipengaruhi pembagian ilmu menjadi tiga macam sebagaimana telah dijelaskan di atas. Ketiga ilmu itu merupakan berbagai materi yang harus dipahami peserta didik dalam proses pendidikannya. Di samping itu, terdapat beberapa aspek lain yang dapat dijadikan sebagai materi pembelajaran kepada peserta didik.

Moralitas (al-adab) merupakan aspek terpenting dalam menilai tingkat pemahaman peserta didik terhadap tauhid, yang direfleksikan dengan ketundukkannya kepada hukum yang berlaku di masyarakat dan aktualisasi nilai-nilai keimanan yang bersangkutan dalam keseharian hidup. Maka, peserta didik di dalam proses pendidikan harus diberikan materi pembelajaran yang mengarahkannya untuk bertindak baik dalam melakukan interaksi dengan anggota masyarakat lain. Ini menunjukkan urgensi pembiasaan nilai-nilai moral dalam diri peserta didik melalui pemberian materi akhlaq.

Berdasarkan uraian di atas, bahwa pendidikan hendak membentuk manusia sempurna yang tercermin dari sosok Nabi SAW, maka hendaknya materi pembelajaran yang diberikan kepada peserta didik juga melakukan akomodasi terhadap tokoh-tokoh yang patut diteladani sejarah hidupnya melalui metode uswah hasanah. Upaya ini tidak hanya dilakukan terhadap tokoh yang telah meninggal dunia, tetapi juga tokoh-tokoh yang masih hidup. Hal ini dapat diwujudkan dengan cara membahas berbagai biografi dari tokoh-tokoh itu sendiri, yang berarti harus mengkaji sejarah yang telah terjadi. Dengan itu semua, diharapkan peserta didik menjadikan tokoh tersebut sebagai teladan yang baik dan mengambil hikmah dari biografi itu, seperti kisah para nabi dengan masyarakatnya yang mengalami dekadensi moral, cerita para sahabat Nabi SAW yang tetap berupaya sekuat tenaga menegakkan ajaran Islam pasca Nabi SAW wafat, cerita tabi'in dan ulama sesudahnya yang tetap berpegang teguh kepada ajaran Islam (Asy'ary, 2002: 60-61.

Meski demikian, materi yang pertama kali harus diberikan kepada peserta didik adalah tauhid, karena materi ini merupakan fondasi dari materi-materi pembelajaran yang lain. Kualitas pemahaman peserta didik dan terhadap realisasinya dalam kehidupan sehari-hari sangat tergantung 
dari keberhasilan dalam materi ini. Oleh karena itu, di dalam tauhid ditekankan kepada pemahaman yang komprehensif terhadap substansi kalimat laa ilaha illa allah dan kalimat syahadat.

\section{Konsep Interaksi Guru dan Peserta Didik}

Dalam kitab Adabul 'Alim wal Muta'alim, Kyai Hasyim sudah mendeskripsikan konsep interaksi guru dan peserta didik ini dengan jelas, termasuk dalam aspek realisasi antara keduanya. Judul itu pula yang menjadi primary sources dari penelitian-penelitian yang telah dilakukan selama ini tentang pemikiran Kyai Hasyim dalam bidang pendidikan.

Menurut Kyai Hasyim, guru merupakan suatu profesi mulia. Segala hal yang berkaitan dengan profesi tersebut, diasumsikan sebagai suatu bentuk ketaatan manusia kepada Tuhannya. Oleh karena itu, motivasi awal yang harus ditanamkan dalam diri guru adalah adanya semangat pengabdian kepada kebenaran dan kebajikan yang tidak mengenal batas ruang dan waktu. Guru tidak boleh terjebak kepada paradigma materalisme yang bersifat temporal.

Guru harus memiliki tingkat profesionalisme yang tinggi dalam mendidik peserta didik. Ini berimplikasi kepada keharusan kualitas, kompetensi dan kapabilitas keilmuan guru yang telah diakui oleh pihak lain serta secara kontinyu tetap berupaya meningkatkan pemahaman keilmuannya dalam bidang keahlian yang diajarkan. Guru juga dituntut untuk memiliki sifat kasih sayang kepada seluruh peserta didiknya, memiliki intelektualitas yang baik, menguasai berbagai metode pengajaran dan memiliki integritas moral yang baik pula, baik secara personal atau sosial.

Secara lebih spesifik, pemikiran Kyai Hasyim tentang konsep guru ini dapat dibedakan menjadi dua kategori, yaitu secara personal dan profesional. Dalam konteks kualitas personal, seorang guru harus mau dan mampu berupaya untuk selalu mendekatkan diri (muraqabah) kepada Tuhan, mematuhi segala peraturan-peraturan hukum-Nya, bersikap sederhana, tenang, qana'ah dan menunjukkan ketaatan yang baik dalam menjalankan ritualitas kepada Tuhannya. Dalam memperhatikan dan memperlakukan peserta didik, guru tidak boleh menunjukkan sikap diskriminatif, yaitu 
dengan cara tanpa melihat background dan status sosial yang kaya atau miskin. Di samping itu, guru harus tetap berupaya memberikan teladan yang baik kepada lingkungan masyarakatnya, melalui pelaksanaan hal-hal yang bersifat sunnah, seperti shalat fardhu berjama'ah di masjid, membudayakan salam, membaca al-Qur'an, puasa sunnah dan sebagainya.

Dalam konteks kualitas profesional, seorang guru dituntut memiliki komitmen dan integritas yang tinggi untuk selalu meningkatkan kualitas profesionalisme, dengan cara membaca, mengkaji dan menelaah secara seksama berbagai informasi yang berkaitan dengan profesinya tersebut. Guru dapat memperoleh penambahan informasi tersebut dari berbagai pihak yang memiliki kompetensi dalam hal yang diinginkan, terlepas dari background sumber belajar itu sendiri, seperti status, keturunan, usia dan sebagainya. Guru dituntut untuk mampu memahami dan menjelaskan materi pembelajaran secara sederhana melalui bahasa yang mudah dipahami siswa dan memberikan prioritas kepada materi pembelajaran yang lebih penting, seperti tafsir, hadits, ushul fiqh, ilmu nahwu dan sebagainya. Materi yang diberikan harus sesuai dengan tingkat perkembangan dan intelektualitas peserta didik, tidak terlalu mudah atau terlalu sulit. Ini penting ditekankan agar keadaan peserta didik tidak mudah merasa dibebani dengan materi pembelajaran yang telah diberikan, sehingga peserta didik tetap fresh, enjoy dan tidak mudah bosan dalam belajarnya.

Ketika sedang melakukan proses pembelajaran, seorang guru dituntut untuk menjaga penampilan fisik. Artinya, guru tidak boleh terlalu berlebihan (glamour) ataupun terlalu sederhana dengan penampilan, harus disesuaikan dengan mata pelajaran dan lingkungan. Guru harus menjaga kondisi fisik dan stamina, tidak boleh mengajar dalam keadaan mengantuk, sangat lapar, mudah marah dan sebagainya. Ketika menerangkan materi, suara yang dikeluarkan juga harus disesuaikan, tidak boleh terlalu keras dan terlalu pelan, terlebih membentak peserta didik.

Ketika sedang melaksanakan pembelajaran, guru harus memiliki tingkat konsentrasi yang penuh, sehingga guru tidak mudah membahas sesuatu yang tidak berkaitan dengan materi pembelajaran dan tidak ada manfaatnya. Ketika di kelas terdapat peserta didik baru, maka guru harus memperhatikan keberadaannya, mengingat peserta didik tersebut membutuhkan perhatian yang lebih dari guru. Jika terdapat pertanyaan 
dari peserta didik dan guru belum mengetahui jawabannya, maka guru harus jujur (sportif) bahwa hal tersebut memang belum diketahuinya, tidak boleh mencari-cari jawabannya agar tidak diasumsikan peserta didik sebagai guru yang tidak berkualitas. Tetapi hal tersebut justeru menunjukkan kualitas keagamaan guru yang sudah baik, dengan tidak melakukan suatu kebohongan kepada peserta didiknya. Namun jika memang guru mengetahui jawaban dari pertanyaan tersebut, maka argumentasi yang disampaikan guru harus dibangun dan berdasarkan atas kerangka pikir (manhajul fikr) yang kuat dan rasional, agar diskusi yang berjalan terhindar dari kesalahpahaman dan tidak berupa "debat kusir" yang tidak menghasilkan sesuatu apapun.

Dalam memberikan materi pembelajaran, guru harus membuka dan menutup setiap pertemuan dengan baik, membukanya dengan basmallah dan menutupnya dengan wallahu a'lam. Sebelum meninggalkan kelas, guru hendaknya melakukan presensi terhadap peserta didiknya dan memberikan beberapa pertanyaan untuk mengukur tingkat pemahaman peserta didik terhadap materi pembelajaran yang baru disampaikan (reflection). Jika terdapat peserta didik yang tidak mengikuti pelajaran dikarenakan sakit, hendaknya guru menjenguknya sebagai bentuk perhatian kepada peserta didiknya tersebut (home visiting). Sebagai bentuk final evaluation, maka dalam kurun waktu tertentu guru harus melakukan ujian terhadap peserta didiknya. Peserta didik yang telah mampu memahami materi pembelajaran dengan baik, dapat dinyatakan telah lulus. Tetapi jika terdapat peserta didik yang belum memahaminya dengan baik, guru harus melakukan ujian remidi terhadap peserta didik itu.

Untuk mengantisipasi agar tidak mengalami ujian remedi ini, maka peserta didik harus berupaya sekuat tenaga dalam meraih keberhasilan yang diinginkan, sehingga hal ini mengakibatkan banyaknya aktivitas positif yang harus dilakukan. Di samping itu, peserta didik harus memiliki integritas moral (akhlaq) yang baik dan menghindari perilaku buruk di masyarakat. Itu semua akan menjadi lengkap jika peserta didik memiliki kemauan yang keras untuk mencari ilmu dan tidak terjebak ke dalam paradigma pragmatisme-materialisme ketika sedang mencari ilmu. Hal ini sangat membantu peserta didik dalam belajar karena akan terbebas dari tuntutan psikologis, seperti meraih jabatan, mengumpulkan kekayaan, 
memperoleh popularitas dan sebagainya.

Secara kontinyu, peserta didik harus mengikuti proses pembelajaran yang dilaksanakan gurunya dengan tekun dan penuh konsentrasi. Peserta didik harus mampu mengatur waktu yang dimilikinya dengan baik, sehingga semangat dan komitmennya dalam belajar tidak menjadi lemah. Terhadap berbagai materi pembelajaran yang disampaikan guru, peserta didik harus menganalisisnya dengan cermat, mengingat itu akan menjadi tolok ukur yang tepat untuk mengukur kesuksesan peserta didik dalam belajar, bukan diukur dari segala hal yang dapat dilihat panca indera dengan mudah.

Peserta didik harus patuh dan taat kepada guru, selama tidak melanggar ajaran Islam dan norma yang berlaku di masyarakat sekitar. Segala kritik dan koreksi dari peserta didik yang diberikan kepada guru harus dilakukan dengan tetap memperhatikan akhlaqul karimah. Sedangkan ketika guru mengomentari kesalahan yang dilakukan peserta didik, maka hal tersebut hendaknya mampu direspon peserta didik sebagai sesuatu yang bersifat konstruktif dan berguna bagi masa depan peserta didik sendiri, tidak direspon secara emosional. Kritik dari guru itu harus diterima peserta didik sebagaimana seorang pasien yang memperoleh nasihat-nasihat dari dokter demi penyembuhan penyakit yang dideritanya.

Menurut Kyai Hasyim, sebenarnya interaksi yang dilakukan peserta didik dengan gurunya lebih mempengaruhi tingkat keberhasilan siswa peserta didik dalam belajarnya, dibandingkan dengan hanya mempelajari materi pembelajaran yang telah disampaikan di kelas. Oleh karena itu, Kyai Hasyim menyarankan agar peserta didik sering berinteraksi dengan orangorang yang memiliki tingkat keilmuan dari pada hanya mempelajari ilmu itu sendiri. Jika tidak mampu melaksanakannya dengan baik, hendaknya peserta didik mampu lebih berkonsentrasi dalam mempelajari materi pembelajaran yang ada, agar waktu yang ada tidak terbuang dengan percuma.

\section{5. $\quad$ Lingkungan Pendidikan}

Perhatian Kyai Hasyim terhadap lingkungan sangat besar, mengingat lingkungan merupakan faktor yang lebih dominan dari pada keturunan (heredity) dalam pendidikan. Lingkungan inilah yang, jika tidak mampu 
melakukan filterisasi dengan baik dan benar, mengakibatkan kelahiran berbagai dampak negatif dalam diri peserta didik. Peserta didik dengan mudah akan menggunakan waktunya untuk melakukan aktivitas yang tidak berkaitan dengan belajar, sehingga hal tersebut pada akhirnya mengganggu konsentrasi dalam belajar.

Bagi Kyai Hasyim, kehadiran Islam tidak hanya berupaya membentuk manusia yang berakidah monoteis (tauhid), tetapi juga memajukan aspek sosial, politik dan ekonomi suatu masyarakat yang terbelakang. Selain itu, Islam juga berupaya memupuk semangat persaudaraan Islam dengan menghilangkan segala perbedaan yang disebabkan oleh faktor hereditas, kekayaan, jabatan atau etnisitas. Dengan itu, diharapkan dapat terbangun fondasi demokrasi yang sangat menghargai humanisme sebagaimana telah diperkenalkan pada peradaban Islam periode awal.

Pendidikan, menurut Kyai Hasyim, pada hakikatnya merupakan tanggung jawab orang tua peserta didik, terutama dari pihak ibu. Tanggung jawab tersebut melekat sampai dengan peserta didik telah dianggap dewasa dan mampu untuk hidup secara mandiri. Di samping itu, orang tua juga memiliki kewajiban untuk memberikan nama yang baik saat bayi baru lahir dan memberikan makanan yang baik pula.

Peran keluarga terhadap pembentukan peserta didik yang sukses dalam pendidikannya sangat penting dan dominan. Oleh karena itu, Kyai Hasyim menyarankan agar persiapan untuk mewujudkan hal itu harus sudah dilakukan ketika seseorang (calon suami) yang diharapkan mampu memenuhi kriteria sebagai ibu yang dapat dipercaya untuk mengemban amanat dan dalam mempersiapkan peserta didik yang memiliki intelektualitas dan kualitas keberagamaan yang baik. Oleh karena itu, wanita yang baik untuk dijadikan (calon) isteri adalah yang memiliki moralitas baik, masih perawan, sederajat ( $k u f u$ ') dan sebagainya. Hal ini dilakukan sebagai upaya untuk mengantisipasi terjadinya dominasi faktor hereditas dalam pertumbuhan dan perkembangan peserta didik ketika berproses dalam pendidikannya.

Dalam lingkungan masyarakat, Kyai Hasyim menekankan agar peserta didik berinteraksi dengan anggota masyarakat yang lain, mengingat manusia adalah homo social yang pasti membutuhkan bantuan yang lain, tidak bisa hidup dengan dirinya sendiri. Manusia merupakan anggota 
masyarakat yang memiliki peran dan kontribusi besar dalam menjaga eksistensi interaksinya dengan anggota masyarakat lain, yang dengan itu semua dapat menjadi sebuah kesatuan yang kuat. Dengan itu semua, maka yang menjadi tujuan bersama suatu masyarakat akan dengan mudah tercapai. Berbagai halangan dan rintangan dapat diatasi dengan mudah jika persatuan dan kesatuan dapat terjaga dengan baik.

Masyarakat merupakan "laboratorium nyata" dari perkembangan peserta didik. Peristiwa yang ada di masyarakat akan berpengaruh ke peserta didik, secara langsung maupun tidak langsung. Dengan memiliki durasi waktu yang jauh lebih lama dari pada sekolah dalam hal keberadaan peserta didik di dalamnya, masyarakat adalah faktor dominan dalam mewujudkan kesuksesan peserta didik ketika belajar. Oleh karena itu, peserta didik dituntut mampu menilai dan memilih berbagai nilai-nilai yang berlaku di dalam masyarakat, baik yang positif maupun yang negatif. Jika hal ini tidak dilakukan, dikhawatirkan peserta didik memiliki pola pikir yang sempit dan pada akhirnya hanya melahirkan fanatisme (ta'ashub) yang sebenarnya tidak diperlukan. Fanatisme buta inilah yang, jika tidak mampu diminimalisasi keberadaannya, akan mengakibatkan perpecahan dalam masyarakat.

\section{Penutup}

Berdasarkan uraian di atas, dapat disimpulkan bahwa Kyai Hasyim merupakan sosok pejuang yang multidimensi. Hal ini berdasarkan fakta bahwa bidang yang menjadi pengabdian Kyai Hasyim tidak hanya satu, tetapi meliputi pendidikan, politik, sosial, agama, konfrontasi fisik, organisasi, karya intelektual dan sebagainya. Tidak hanya mencerdaskan anak bangsa melalui pesantren Tebuireng yang didirikan, tetapi bagi generasi selanjutnya, Kyai Hasyim telah mewariskan banyak buku atau kitab yang mampu dijadikan sebagai referensi utama dalam mencari alternatif solusi dari berbagai problematika yang sedang dihadapi bangsa.

Fatwa Resolusi Jihad yang dikeluarkan bersama ulama NU di Surabaya juga terbukti mampu memobilisasi massa untuk melawan Belanda, meski buku-buku sejarah belum banyak membahasnya. Sikap Kyai Hasyim yang rendah hati, terbukti menolak Jepang meski ditawari dengan jabatan 
presiden sekalipun, menunjukkan sebagai karakter yang harus dicontoh generasi bangsa. Semangat Kya Hasyim yang tidak mengenal lelah dan putus asa dalam menimba ilmu, meskipun berasal dari garis keturunan seorang bangsawan dan kyai besar, sudah saatnya menjadi spirit bagi generasi muda untuk mengejar ketertinggalan Indonesia dari bangsabangsa lainnya.

Konsistensi Kyai Hasyim dalam mempertahankan ajaran agama Islam, terutama dari aspek 'aqidah, menjadi karakter tersendiri dalam menghadapi arus besar globalisasi seperti jaman modern ini. Rasa cinta yang mendalam dari Kya Hasyim terhadap kemerdekaan Indonesia patut menjadi suri teladan dan karakter bagi generasi muda Indonesia saat ini dalam mengisi kemerdekaan itu sendiri. Nasionalisme yang ditunjukkan Kyai Hasyim merupakan karakter utama yang patut dicontoh oleh generasi penerus bangsa dalam mempetahankan identitas bangsa di tengah percaturan dunia modern yang semakin global.

Di sisi lain, Kyai Hasyim sebenarnya sudah memberikan kerangka konsepsional yang fundamental bagi pendidikan Indonesia. Langkah lebih teknis operasional memang harus tetap dikaji ulang untuk mengimplementasikan pemikiran pendidikan Kyai Hasyim ini. Sosok pendiri NU ini pada titik tertentu hendak melakukan balancing terhadap dunia pendidikan di Indonesia. Tidak sekedar aspek formalitas, tetapi juga subtansi dari makna pendidikan harus diinternalisasikan dan diimplementasikan dalam kehidupan peserta didik. Pada ujungnya, diharapkan pendidikan Indonesia mampu melahirkan "produk" yang tidak hanya memiliki intelektual (pinter), tetapi juga memiliki integritas moral yang baik (bener).

\section{Daftar Pustaka}

Adnan, Abdul Basit. 1982. Kemelut di NU, Antara Kyai dan Politisi. Solo : Mayasari.

Akarhanaf. 1950.Kiai Hasjim Asj'ari; Bapak Umat Islam Indonesia. Jombang : Pondok Tebuireng.

Anam, Choirul. 1985. Pertumbuhan dan Perkembangan Nahdlatul Ulama. Solo : Jatayu.

Arifin, Imron. 1993.Kepemimpinan Kyai. Malang: Kalimasada. 
Asy'ari, Hasyim. 1417 H. al-Tanbihat wal Wajibat. Jombang : Maktabah al-Turats al-Islamy. . al-Tibyan. 1998.Jombang : Maktabah al-Turats al-Islamy. . 1995.Adabul 'Alim wal Muta'allim. Jombang : Maktabah al-Turats al-Islamy.

. 1998.al-Nurul Mubin. Jombang : Maktabah al-Turats al-Islamy. . 1998.Risalah Ahli Sunnah wal Jama'ah. Jombang : Maktabah alTurats al-Islamy. . 1995.Ziyadatut Ta'liqat. Jombang : Maktabah al-Turats al-Islamy. . 1999. Dhau'ul Misbah. Jombang : Maktabah al-Turats al-Islamy. . 1974.al-Durar al-Muntatsirah, terj. M. Tolchah Mansoer. Kudus : Menara.

Atjeh, Aboebakar. 1957.Sedjarah Hidup KH. A. Wahid Hasjim dan Karangan Tersiar. Jakarta : Panitia Buku KH. A. Wahid Hasjim.

Baker, Anton. 1990.Metodologi Penelitian Filsafat. Yogyakarta : Kanisius. Dhofier, Zamakhsyari. 1982.Tradisi Pesantren. Jakarta : LP3ES.

Fauzia, Nia Kurnia Amelia. 2002.

“Gerakan Modernisme,” Ensiklopedi Tematis Dunia Islam, vol. 5, ed. Taufiq Abdullah dkk. Jakarta : Ichtiar Baru van Hoeve.

Federspiel. Howard M. 2000. "Kata Pengantar" dalam Lathiful Khuluq, Fajar Kebangunan Ulama. Yogyakarta : LKiS.

Geertz, Clifford. 1960.The Religion of Java. Amerika : The Free Press.

Gunseikanbu. 1960.Orang Indonesia yang Terkemuka di Jawa. Yogyakarta : Gajah Mada University Press.

Hadziq, Muhammad Ishamuddin. 1995."al-Ta'rif bil Mu'allif," dalam Muhammad Hasyim Asy'ari, Ziyadatut Ta'liqat. Jombang : Maktabah al-Turats al-Islamy. . 1999. KH. Hasyim Asy'ari, Figur Ulama dan Pejuang Sejati. Jombang : Pustaka Warisan Islam. . 1995. “At-Ta'rif bil Mu'allif” dalam Adabul 'Alim wal Muta'allim. Jombang : Maktabah al-Turats al-Islamy. 
Hillway, Tyrus. 1964.Introduction to Research. Boston : Houghton Mifflin Company.

Hodgson, Marshall G.S. 1974.The Venture of Islam, vol. 1. Chicago : The University of Chicago Press.

Imron, Fuad Amin. 2012.Syaikhona Kholil Bangkalan, Penentu Berdirinya Nahdlatul Ulama. Surabaya : Khalista.

Iskandar, M. dan A. Syahid, 2002."Islam dan Kolonialisme,” Ensiklopedi Tematis Dunia Islam, vol. 5, ed. Taufiq Abdullah dkk. Jakarta : Ichtiar Baru van Hoeve.

Khuluq, Lathiful. 2000.Fajar Kebangunan Ulama. Yogyakarta : LKiS.

Madjid, Nurcholis. 1992.Islam, Doktrin dan Peradaban. Jakarta : Paramadina.

Mintz, Jeanne S. 2002. Muhammad, Marx, Marhaen; Akar Sosialisme di Indonesia, terj. Zulhilmiyasari. Yogyakarta : Pustaka Pelajar.

Misrawi, Zuhairi. 2010.Hadratussyaikh Hasyim Asy'ari, Moderasi, Keumatan dan Kebangsaan. Jakarta : Kompas.

Muchtarom, Zaini. 1988.Santri dan Abangan di Jawa. Jakarta : INIS.

Nasution, Harun. 1992. Pembaharuan Dalam Islam. Jakarta : Bulan Bintang.

Salam, Solichin. 1963. KH. Hasyim Asy'ari; Ulama Besar Indonesia. Jakarta : Djaja Murni.

Saleh, Fauzan. 2005.Teologi Pembaruan. Jakarta : Serambi.

Soekardi, Heru. 1985.Kyai Haji Hasyi Asy'ari; Riwayat Hidup dan Perjuangannya (Jakarta : Depdikbud.

Subhan, Muhammad. 2013."Marhaban Ya Sang Kiai,” Majalah Aula, Edisi XXXV, Juli.

Suriasumantri, Jujun S. 1988.Filsafat Ilmu. Jakarta : Pustaka Sinar Harapan.

Syihab, Muhammad As'ad. 1994.Hadratussyaikh Muhammad Hasyim Asy'ari ; Perintis Kemerdekaan Indonesia, terj. A. Musthofa Bisri. Yogyakarta : Titian Ilahi. 